15 Anon. The use of opioids for the treatment of chronic pain: a consensus statement from the American Academy of Pain Medicine and the American Pain Society. Pain Forum 1997;6:77-9.

16 Cummings-Ajemian I. Treatment of related symptoms. In: RB Patt, ed. Cancer pain, section III, nom-pharmacological treatment and novel approaches to management. Philadelphia:JB Lippincott, 1993.

17 Jeal W, Benfield P. Transdermal fentanyl-a review of its pharmacological properties and therapeutic efficacy in pain control. Drugs 1997;53: 109-38.

18 Grond S, Zech D, Lehman KA, Radbruch L, Breintenbach H, Hertel D. Transdermal fentanyl in the long-term treatment of cancer pain: a prospective study of 50 patients with advanced cancer of the gastrointestinal tract or the head and neck origin. Pain 1997;69:191-8.

19 Donner B, Zenz M, Tryba M, Strumpf M. Direct conversion from oral morphine to transdermal fentanyl: a multicentre study in patients with cancer pain. Pain 1996;64:527-34.

20 Donner B, Zenz M, Strumpf M, Raber M. Long-term treatment of cancer pain with transdermal fentanyl. J Pain Symptom Manage 1998;15: 168-75.

21 Ahmedzai S, Brooks D. Transdermal fentanyl versus sustained release oral morphine in cancer pain: preference, efficacy, and quality of life. $J$ Pain Symptom Manage 1997;13:254-61.

22 Payne R, Mathias SD, Pasta DJ, Wanke LA, Williams R, Mahmoud R. Quality of life and cancer pain: satisfaction and side effects with transdermal fentanyl versus oral morphine. J Clin Oncol 1998;16:1588-93.

23 Dellemijn, PLI, van Duijn H, Vanneste JAL. Prolonged treatment with transdermal fentanyl in neuropathic pain. J Pain Symptom Manage 1998;16:220-9.

24 TTS-Fentanyl Multicentre Study Group. Transdermal fentanyl in cancer pain. J Drug Dev 1994;6:93-7.

25 Zech DFJ, Grond SAU, Dauer HG, Stollenwerk B, Lehmann KA Transdermal fentanyl and initial dose-finding with patient-controlled analgesia in cancer pain. A pilot study with 20 terminally ill cancer patients. Pain 1992;50:293-301.

26 Southam MA. Transdermal fentanyl therapy: system design, pharmacokinetics and efficacy. Anticancer Drugs 1995;6(suppl 3):29-34.

27 Ware JE, Sherbourne CD. The MOS 36-item short-form health survey (SF-36). I. Conceptional framework and item selection. Med Care 1992:30:473-83.

28 Koch CG. The use of non-parametric methods in the statistical analysis of the two period change-over design. Biometrics 1972;28:577-84.
29 Watson HR, Pearce AC. Treatment allocation in clinical trials: randomisation and minimisation compared in three test cases. Pharmaceut Med 1990;4:207-12.

30 Collett B-J. Opioid tolerance: the clinical perspective. $\mathrm{Br} J$ Anaesth 1998;81:58-68.

31 Bruera E, Sloan P, Mount B, Scott J, Suarez-Almazar M. A randomized, double-blind, double-dummy, crossover trial comparing the safety and efficacy of oral sustained-release hydromorphine with immediaterelease hydromorphine in patients with cancer pain. J Clin Oncol 1996; 14:1713-7.

32 Amanzio M, Benedetti F. Neuropharmacological dissection of placebo analgesia: expectation-activated opioid systems versus conditioningactivated specific subsystems. J Neurosci 1999;19:484-94.

33 Uhl GR, Sora I, Wang Z. The mu opiate receptor as a candidate gene for pain: polymorphisms, variations in expression, nociception, and opiate responses. Proc NatlAcad Sci 1999;96:7752-5.

34 Megens AAHP, Artois K, Vermeire J, Meert T, Awouters FHL. Comparison of the analgesic and intestinal effects of fentanyl and morphine in rats. J Pain Symptom Manage 1998;15:253-8.

35 McQuay HJ, Jadad AR, Carroll D, Faura C, Glynn CJ, Moore RA, et al. Opioid sensitivity of chronic pain: a patient-controlled analgesia method. Anaesthesia 1992;47:757-67.

36 Moore RA, Gavaghan D, Tramer MR, Collins SL, McQuay HJ. Size is everything-large amounts of information are needed to overcome random effects in estimating direction and magnitude of treatment effects. Pain 1998;78:209-16.

37 Haynes B. Can it work? Does it work? Is it worth it? BMJ 1999;319:652-3.

38 Max M. Methodological issues in the design of analgesic clinical trials. In: Mitchell M, ed. Pain 1999-an update review. Seattle: IASP Press, 1999.

39 Tramer MR. When placebo controlled trials are essential and equivalence trials are inadequate. BMJ 1998;317:875-80.

40 Torgerson DJ, Sibbald B. Understanding controlled trials: what is a patient preference trial? BMJ 1998;316:360.

41 Senn S. Within-patient studies: cross-over trials and n-of-1 studies. In: Mitchell M, ed. Pain 1999-an update review. Seattle: IASP Press, 1999.

42 Goodare H, Lockwood S. Involving patients in clinical research. BMJ 1999;319:724-5.

(Accepted 13 December 2000)

\title{
General practitioners' reasons for removing patients from their lists: postal survey in England and Wales
}

\author{
Mark Pickin, Fiona Sampson, James Munro, Jon Nicholl
}

Medical Care

Research Unit,

University of

Sheffield, Sheffield

S1 4DA

Mark Pickin

clinical senior lecturer

Fiona Sampson

research fellow

James Munro

clinical senior lecturer

Jon Nicholl

professor

Correspondence to:

M Pickin

d.m.pickin@

sheffield.ac.uk

BMJ 2001;322:1158-9
The removal of patients from doctors' lists causes considerable public and political concern, with speculation that patients are removed for inappropriate, including financial, reasons. ${ }^{1}$ In 1999 the House of Commons Select Committee on Public Administration noted that little evidence was available on either the frequency of, or the reasons for, removal of patients. ${ }^{2}$ National statistics do not distinguish between patients removed after moving out of a practice area and those removed for other reasons. Two postal surveys have reported why general practitioners might, in general, remove patients, ${ }^{34}$ and one small study has described the reasons doctors give for particular removals. ${ }^{5}$ We therefore determined the current scale of, and doctors' reasons for, removal of patients from their lists in England and Wales.

\section{Participants, methods, and results}

In April 2000 we sent a questionnaire to 1000 general practitioners in a random sample of practices, but to no more than one doctor per practice. Up to two reminders were sent to non-respondents at fortnightly intervals.

The questionnaire asked for the number of patients removed from the practice list in the previous six months (for reasons other than living outside the practice area), the reasons contributing to the most recent removal, and whether that removed patient was given a reason. A list of suggested reasons for removal was included (having been compiled in the light of published opinions ${ }^{35}$ ), and respondents were asked to indicate which of these were "primary" reasons and which others were "contributory."

The questionnaire also asked whether target payment systems (for childhood immunisation and cervical smear testing) and financial arrangements for drug budgets and out of hours care created financial incentives for removing patients.

Of the 1000 doctors surveyed, 14 replied that they were not working in general practice. Of the remaining 986, $748(76 \%)$ responded. In the previous six months 300 out of 745 practices $(40 \%$ (95\% confidence interval $37 \%$ to $44 \%)$ ) had removed one or more patients. When 21 practices whose list size was not stated were excluded, 988 patients had been removed during this period from a registered population of 4.6 million, (removal rate of 4.3 (4.1 to 4.6) per 10000 patients a year).

The primary and contributory reasons given for the most recent removal by each of these 300 practices are shown in the table. Violent, threatening, or abusive behaviour was given as a primary reason in 176 of 
300 removals $(59 \% \quad(53 \%$ to $64 \%))$ and as a contributory reason in a further 24 (8\%). Other primary reasons given were complaint by a patient $(5$ (2\%) cases), non-compliance with childhood immunisation $(4(1 \%))$, and non-compliance with cervical smear testing $(2(7 \%))$.

In 238 of $288(83 \%(78 \%$ to $87 \%))$ most recent removals, the practice had given the patient a reason for the removal, either in writing $(55 \%(157))$ or in person $(28 \%(81))$.

About half of general practitioners believed that the target payment systems for childhood immunisation (370/732) and cervical smear testing (360/732) had created financial incentives to remove patients. Smaller, but still substantial, proportions of respondents considered that financial arrangements for practice drug budgets $(295 / 728)$ and out of hours care $(321 / 733)$ also created such incentives.

\section{Comment}

General practitioners report that violent, threatening, or abusive behaviour by patients is their most common reason for removing a patient from their list. Non-compliance with childhood immunisation or cervical smear testing was rarely reported as a reason, and never as the sole reason, for removal despite the perceived financial incentives for removal.

The validity of our findings depends on doctors being able and willing to identify and report the number of removals and their reasons for them. If our respondents were unaware of all removals from the practice or were not truthful about why they removed patients, our findings will misrepresent the situation. Moreover, patients may have different views of the events leading to removal, which future research should seek to understand.

We thank Stuart Drage, Peter Corpe, and Bernard Horan for their valuable advice and assistance.

Contributors: MP contributed to the study design, helped to write the paper, supervised the survey, and analysed the data. FS administered the survey, contributed to data analysis, and
Primary and contributory reasons given by 300 practices for most recent removal of a patient from their list. Values are numbers (percentages) of practices citing each reason

\begin{tabular}{lcc} 
Reason & Primary & Contributory \\
\hline Violence, threats, or abuse & $176(59)$ & $24(8)$ \\
\hline Drug or substance misuse & $36(12)$ & $51(17)$ \\
\hline Inappropriate demand: & $38(13)$ & $47(16)$ \\
\hline In normal hours & $24(8)$ & $31(10)$ \\
\hline Out of hours & $31(10)$ & $54(18)$ \\
\hline $\begin{array}{l}\text { Inappropriate demand for } \\
\text { medication }\end{array}$ & & $39(13)$ \\
\hline Non-compliance with: & $38(13)$ & $44(15)$ \\
\hline Appointments & $25(8)$ & $5(2)$ \\
\hline Treatment & $4(1)$ & $5(2)$ \\
\hline Childhood immunisation & $2(1)$ & $26(9)$ \\
\hline Cervical smear testing & $44(15)$ & $6(2)$ \\
\hline Deception or crime & $5(2)$ & $6(2)$ \\
\hline Complaint or litigation by patient & $7(2)$ & $3(1)$ \\
\hline Inappropriate sexual behaviour & $3(1)$ & $4(1)$ \\
\hline Request for unconventional & $3(1)$ & $3(1)$ \\
\hline treatment & $2(1)$ & \\
\hline Cultural differences & $11(4)$ & \\
\hline Request for particular kind of \\
general practitioner
\end{tabular}

Some respondents gave more than one primary reason or more than one contributory reason per removal.

helped to write the paper. JM designed the study, contributed to the analysis, and wrote the paper. JN contributed to the study design, data analysis, and helped to write the paper. MP is the guarantor for the paper.

Funding: This work was funded by the Department of Health. The views expressed are those of the authors and not necessarily those of the Department of Health.

Competing interests: None declared.

1 Yamey G. Struck off, but why? BMJ 1999:319:791.

2 House of Commons Select Committee on Public Administration. 2nd report. Annual report of the Health Service Ombudsman for 1997-98 [session 1998-99]. Norwich: Stationery Office, 1999. www.parliament.thestationery-office.co.uk/pa/cm199899/cmselect/cmpubadm/54/ 5402.htm

3 Perry J. Removed from care: a report of patients removed from GP lists at the doctor's request. Maidstone: Kent Family Health Services Authority, 1995.

4 Cummings R, Young S. Patient removals. Sitting pretty. Health Serv J 2000;110(5705):26-7.

5 McDonald J, Campbell C, Anderson L. GP patient removal: a Lothian local medical committee survey. Scottish Medicine 1995;15:10-1.

(Accepted 8 March 2001)

\section{One hundred years ago}

\section{After-dinner speeches}

After-dinner speaking out of the mouths of some few practitioners becomes a science, and nothing can better promote digestion than to set back "serenely full" and listen to the founded periods and elaborate impromptus of someome whose natural gifts have been cultivated by art. Genius has been defined, wrongly we think, as the faculty of taking pains, but there is no doubt that whoever wishes to excel in post-prandial oratory must adopt this course, the absence of which caused the failure of the Vicar of Wakefield's family portrait. On minor occasions anyone possessing a fluent tongue, and knowledge and nerve, and a pinch of the Attic salt of humour will probably speak best on the spur of the moment, but trusting to inspiration may sometimes prove a broken reed, and those who have to obey the orders of the toast master when important issues are at stake may be advised to make more or less careful preparation. When the late Sir James Paget had to deliver an important speech he might be met in the Regent's Park pacing round and round, and rehearsing his performance; and Charles Dickens, facile princeps with his tongue as with his pen, would walk miles over Hampstead Heath declaiming and gesticulating when he had to take the chair at a public dinner. On the other hand, over-elaboration becomes a positive evil when it leads to the production and infliction of long dreary harangues which must be continued to their bitter end, with scanty regard to the comfort of the long-suffering audience.

(BMJ 1901;ii:910) 